\title{
Occupational and Environmental Risk Factors for Development of Low Back Pain in Hospital Nursing Personnel
}

\author{
Jadranka Stričević́ ${ }^{1}$ Zvone Balantič2 ${ }^{2}$ Zmago Turk ${ }^{3}$, \\ Dušan Čelan ${ }^{3}$ and Majda Pajnkihar ${ }^{1}$ \\ ${ }^{1}$ Faculty of Health Sciences, University of Maribor, Maribor, \\ ${ }^{2}$ Faculty of Organisational Sciences, University of Maribor, Kranj, \\ ${ }^{3}$ University Clinical Center Maribor, Maribor, \\ Slovenia
}

\section{Introduction}

Nursing was in the past identified as an occupation whose practitioners were at risk of developing low back pain (LBP) (Engkvist et al., 1998; Hoogendoorn et al., 1999; Goldman et al., 2000). Providing nursing care is related to frequent flexion and extension of the body, including manual lifting (Cromie et al., 2000; Elford et al., 2000; Hui et al., 2001; Daynard et al., 2001). Activities connected to lifting and transferring patients represent major physical demands for nursing personnel, which in many cases result in injuries (Marras et al., 1999; Retsas \& Pinikahaba, 2000). Some European countries calculate costs related to LBP treatment at around 1\% of yearly gross domestic product (van Tulder et al., 1995; Hansson \& Hansson, 2005). Among the musculoskeletal disorders, LBP represents the most frequent incident and the most expensive treatment (Balantič \& Zupan, 2003, Whiting \& Zernicke, 2008). In a German research the cost for a single episode of LBP was estimated to amount approximately to EUR 1300 in medical costs and loss of production (Wenig et al., 2009). The literature estimates that among adults in the general population, $70-85 \%$ are believed to experience at least one episode of low back pain at some time during their lifetime (Andersson, 1999; Croft et al., 1999).

The problem of LBP in nursing has been thoroughly researched and the main risks are known, and measures have been suggested for its prevention. Success was in most cases reported as adhering to a 'zero lift policy' by using assistive devices (Zhuang et al., 1999, 2000; Nelson et al., 2003a; Collins et al., 2004; Menzel et al., 2004, Nelson et al., 2006). However, the problem of awkward body postures remains, as it is difficult to avoid these altogether (Smedley et al., 1995; Elford et al., 2000). Biomechanical research revealed the human effort in manual lifting, change of patient position in bed, patient transfer from bed to wheelchair or stretcher, patient transfer from wheelchair to toilet and vice versa as major risks for developing LBP (Owen \& Garg, 1989; Owen et al., 2002). Therefore it seems reasonable that nursing personnel should remain in good physical condition, not being overweight, with a supple and firm body. Although body mass index (BMI) was not clearly 
associated with LBP in the past, research has since shown that low BMI may also represent a risk (Lagerstrom et al., 1995; Kerr et al., 2001; Smedley et al., 2003). Older research also examined smoking and alcohol consumption and concluded that this might represent some risk (Frymoyer et al., 1980; Kelsey et al., 1984; Bigos et al., 1986; Heliovaara et al., 1987). Following literature reviews by Ferguson and Marras (1997) and Rubin (2007), these authors summarised the risk factors for developing LBP in advanced age as being female, having a lower economic standard, lower education, smoking, frail health, physical work, repeated tasks, awkward body postures, lower job satisfaction, depression, spinal structure and visible spinal anomalies.

The international literature suggested four major solutions to prevent LBP in nursing personnel. While the 'zero lift policy' is the most promising among the four strategies, unfortunately it is also the most expensive, because technical equipment needs to be purchased (Nelson et al., 2006). Technical equipment in nursing care provision is only useful if the amount of needed force to handle the equipment does not exceed the forces that are developed by manual handling and lifting (Santaguida et al., 2005). The other three solutions introduced were manual lifting techniques (Larese \& Fiorito, 1994; Daltroy, 1997; Lagerstrom \& Hagberg, 1997; Hye-Knudsen et al. 2004; Karahan \& Bayraktar, 2004), forming nursing personnel or special workforces into so called 'lift teams' (Charney, 1997) and introducing regular prevention exercising (Linton \& van Tulder, 2001; Rainville et al., 2004; Burton et al., 2005; Byrne et al., 2006).

Several studies that researched improvements in LBP development by applying manual lifting techniques showed no positive long-term effects (Larese \& Fiorito, 1994; Daltroy, 1997; Lagerstrom \& Hagberg, 1997; Nelson et al., 2003b). Many older Asiatic traditional motion techniques are currently revived, introducing new manual lifting techniques to best overcome physical burden. Marras et al. (1999) concluded that the essential problem in using manual lifting techniques is the human factor, where stressful working conditions and unexpected situations may eventually lead to failures. From a financial aspect manual, lifting techniques are most popular as a prevention strategy because they cost least.

Heavy lifting became a legislative issue in the 1970s and 1980s to prevent occupational activities that might harm workers' health. In the USA the National Institute on Safety and Health recommended the maximum spinal compression force should be $3400 \mathrm{~N}$ for heavy manual lifting or manual transfer (NIOSH, 1981, 1994). Zhuang et al. (1999) showed that in performing manual patient transfer, specifically turning a patient in bed and lifting the patient to a sitting position in bed on average exceeds this recommended limit. This was especially evident in care activities of overweight patients. Additional research on different manual lifting techniques in team work in patients weighing more than $75 \mathrm{~kg}$ resulted in spinal compression forces over the recommended threshold of $3400 \mathrm{~N}$ (Winkelmolen et al., 1994). Nursing personnel are by their occupational duties regularly exposed to burdens that exceed these limits.

The International Labour Organisation (ILO) issued two conventions that are more closely connected to nursing care provision, (1) (Maximum Weight Convention) and (2) C155 (Occupational Safety and Health Convention). The Maximum Weight Convention was adopted on 28 June 1967 and states that no worker shall be required or permitted to engage in the manual transport of a load which, by reason of its weight, is likely to jeopardise the 
worker's health or safety. In addition, the employer shall take appropriate steps to ensure that any worker assigned to manual transport of loads other than light loads receives, prior to such assignments, adequate training or instruction in working techniques, with a view to safeguarding health and preventing accidents. The Occupational Safety and Health Convention, adopted 22 June 1981, aims to prevent accidents and injury to health arising out of, linked with or occurring in the course of work, by minimising, so far as is reasonably practicable, the causes of hazards inherent in the working environment (European Agency for Safety and Health at Work, 2008).

The European community mandates certain directives in connection with occupational safety, with each member country having the right to implement the directives according to their own means. Member countries can adopt more intense regulations within individual directives, although this is seldom the case due to economic interests to remain competitiveness with Eastern countries. In general, adopted directives are not intended for certain economic branches and are also not directly connected to musculoskeletal disorders; they give general guidelines to improve occupational health and. Council directive 89/391/EEC obligates employers to introduce measures to encourage improvements in the health and safety of workers at work, whereas information, dialogue and balanced participation on health and safety at work must be developed between employers and workers (Council Directive 89/391/EEC, 1989).

Council directive 90/269/EEC was adopted on 29 May 1990 and supplements the general council directive about measures for occupational health and safety (89/391/EEC) on the minimum health and safety requirements for the manual handling of loads where there is a risk, particularly of back injury, to workers. The general provision states that the employer shall take appropriate organizational measures, or shall use the appropriate means, in particular mechanical equipment, in order to avoid the need for the manual handling of loads by workers. In addition, wherever the need for manual handling of loads by workers cannot be avoided, the employer shall organize workstations in such a way as to make such handling as safe and healthy as possible. Assessment must be made, in advance if possible, of the health and safety conditions of the type of work involved, and in particular examinations of the characteristics of loads. Employers must ensure that workers and/or their representatives receive general indications and, where possible, precise information on the weight of a load, and the centre of gravity of the heaviest side when a package is eccentrically loaded. Employers must ensure that in addition workers receive proper training and information on how to handle loads correctly and the risks they might be open to, particularly if these tasks are not performed correctly (Council directive 90/269/EGS, 1990).

Several studies have indicated that LBP may contribute to nursing personnel turnover. For example, Owen (2000) found that $20 \%$ of nursing personnel had changed jobs at least once due to LBP problems. In a survey conducted with over 43,000 members of nursing personnel in five countries, $17 \%$ to $39 \%$ reported that they planned to leave their job in the next year due to the physical and psychological demands of the profession (Aiken et al., 2001). These findings are especially alarming given the current shortage of nursing personnel and the increasing need for nursing care projected over the next decades (Massey et al., 2009; DiMattio et al., 2010). 
To contribute to the above knowledge, the aim of this research was to examine to which extent the occupational and environmental risk factors influence the development of LBP in hospital nursing personnel. According to literature review our research included some occupational risk factors and also some personal characteristics about life style, which were designated as environmental risk factors. Among the risk factors included were also some that were expected to act as prevention for developing LBP. Potential risk or prevention factors were included in a multivariate statistical analysis to conduct factors that best predict development of LBP. In the discussion and conclusion sections we introduce some ideas, suggestions and considerations how our results could be implicated in clinical practice. We also provide some suggestions for future research.

To search in the international literature for similar research strategies as we had applied, we conducted a very general search of electronic databases about LBP and nursing personnel or occupation, followed by a subsequent review of abstracts to find more specific literature. The search in the electronic databases Medline, CINAHL and ScienceDirect resulted in 144 non-overlapping hits. Search terms 'nursing' and 'low back pain' were used by selecting the period from 1990 to 2010 . The inclusion criteria for the literature search were for terms to be found in the title, abstract or keywords. The larger group of hits was related to LBP occupational risks and four articles only included recreation or exercise as potential LBP prevention. Occupational and environmental components of nursing personnel have rarely been analysed at the same time, and Feng et al. (2007) was identified as the only contribution where recreation was considered in the statistical analysis in conjunction with other LBP risks. The literature search was extended beyond 2007 (till end of 2010), where our research design was initial made and also the data gathering concluded, in order to find any up to date scientific advances.

\section{Methods}

As a research method a non-experimental approach with a cross-sectional survey and statistical analysis was used.

\subsection{Instrument}

A structured questionnaire about LBP included basic demographic and anthropometric characteristics: age, gender, body height and body weight. The second part of the instrument included occupational risk factors: duration of employment in years, duration of employment in the current position in years, frequent manual weight lifting above $10 \mathrm{~kg}$, manual patient transfer and material handling, patient transfer and material handling with assistive devices, availability of height adjustable beds in nursing care provision, treatment of patients in the highest patient classification system category, and hours of daily work at the computer. The third part included physical activities and habits (environmental risk factors): regular exercises to prevent LBP, recreation and sports in youth, recreation and sports at present, and hours of watching television. The question representing the depended variable was how many episodes of LBP respondents experienced during their working career. A list of all measured characteristics is included in table 1. Duration of employment, work at the computer and watching TV were split into two groups by median value. BMI was calculated as quotient of body weight in kilograms and square of body height in metres. Overweight was marked as BMI $\geq 25 \mathrm{~kg} / \mathrm{m}^{2}$ (WHO, 2006). 
The structured questionnaire was developed according to literature review about occupational risks connected to development of LBP in nursing personnel, for example, as manual patient transfer, frequent lifting and nursing care provision without the use of assistive devices (Ando et al., 2000; Fairbank \& Pynsent, 2000; Davidson \& Keating, 2002; Trinkoff et al., 2003; Bot et al., 2004). Included were personal characteristics that were considered to have positive or negative effects on LBP, such as being female, physical condition, BMI, preventive exercising, watching TV (Lahad et al., 1994; Ferguson \& Marras, 1997; Maher et al., 1999; Trinkoff et al., 2003; Rainville et al., 2004; Burton et al., 2005; Shehab \& Al-Jarallah 2005; Rubin, 2007).

\subsection{Sample}

The sample consisted of nursing personnel from the University Clinical Center Maribor, the second largest Hospital in Slovenia, with 2800 employees and 1500 members of nursing personnel among them. Hospital nursing personnel in Slovenia involves nursing assistants and registered nurses. Nine hundred questionnaires were distributed among the nursing personnel in 2007, 663 (73.7\%) were returned and 581 (64.6\%) were considered for analysis. Eighty-two (12.4\%) returned questionnaires were excluded due to missing data. Data were collected by convenience sampling. The sample size was selected according to stratification of 40 hospital departments. The strategy in general was to survey $30-40 \%$ of nursing personnel from each hospital department to achieve better reliability of results. Gender distribution was $489(84.2 \%)$ women and $92(15.8 \%)$ men, mean age was $37.5 \pm 8.9$ of years. Frequent LBP was reported in 458 (78.8\%) of cases.

The sample size was determined by exemplars from international cross-sectional survey studies, which tend to gather a sample of approximately 500 participants. These sample sizes generally suffice for the needs of the statistical analysis and also give better representation of the researched population. For the statistical relevance, according to alpha level (p-value) of 0.05, the number of predictors (degrees of freedom) of 15 and the anticipated medium effect (f2) size of 0.15 , in order to achieve desired statistical power level of 0.8 , a sample size of $n=139$ would be needed (Polit, 1996).

\subsection{Statistical analysis}

Sample data was presented by frequency and percentage for categorical variables or by mean value and standard deviation for numerical variables. Median values were calculated to split numerical variables into two groups. Univariate and multivariate statistics for LBP risk was calculated by binary logistic regression. The chi-square $\left(\chi^{2}\right)$, odds ratio (OR), 95\% confidence interval $(95 \% \mathrm{CI})$ and P-value were calculated. Multivariate binary logistic regression was calculated without a method to omit insignificant variables. Statistical analysis was performed with SPSS 15.0 software (SPSS Inc., Chicago, IL). P-value $<0.05$ was marked as statistically significant.

\subsection{Ethical considerations}

Approval for the study was obtained locally from the Nursing Care Office of the University Clinical Center Maribor. The research participants were informed about the nature of the study and what participation would entail for them, by receiving a printed information 
sheet (Puotiniemi \& Kyngäs, 2004). Participants were also asked to contact head nurses of the hospital departments for further questions. Participation in the research was voluntary and anonymous. By applying the stratification by hospital departments, anonymity was to some extend compromised or contracted, nevertheless it was still not possible to recognise the individual participants. Items in the questionnaire were very general; they did not included private items, provoke feelings or address intimate relationship. Items that may potentially harm participants or the University Clinical Center Maribor were also not included in the questionnaire.

\section{Results}

Fifteen variables in the form of risk factors were included in the analysis (Table 1).

\begin{tabular}{|c|c|c|c|c|c|c|}
\hline \multirow{2}{*}{ Risk factor } & \multicolumn{2}{|c|}{ LBP (in \%) } & \multirow[t]{2}{*}{$x^{2}$} & \multirow[t]{2}{*}{ OR } & \multirow[t]{2}{*}{$95 \% \mathrm{CI}$} & \multirow[t]{2}{*}{$P$-value } \\
\hline & $\begin{array}{c}\text { rare } \\
(\mathrm{n}=123)\end{array}$ & $\begin{array}{l}\text { frequent } \\
(\mathrm{n}=458)\end{array}$ & & & & \\
\hline Age $\geq 40 y$ & 26.0 & 53.9 & 28.4 & 3.3 & $2.1-5.2$ & $<0.001$ \\
\hline Female gender & 75.6 & 86.5 & 8.3 & 2.1 & $1.3-3.4$ & 0.004 \\
\hline Duration of employment $\geq 20 y$ & 26.8 & 54.6 & 28.1 & 3.3 & $2.1-5.1$ & $<0.001$ \\
\hline $\begin{array}{l}\text { Duration of employment in } \\
\text { current position } \geq 15 y\end{array}$ & 32.5 & 51.7 & 14.0 & 2.2 & $1.5-3.4$ & 0.001 \\
\hline Frequent manual lifting $>10 \mathrm{~kg}$ & 43.1 & 63.5 & 16.3 & 2.3 & $1.5-3.4$ & $<0.001$ \\
\hline $\begin{array}{l}\text { Manual patient transfer and } \\
\text { material handling }\end{array}$ & 10.6 & 16.2 & 2.3 & 1.6 & $0.8-3.1$ & 0.126 \\
\hline $\begin{array}{l}\text { Patient transfer and material } \\
\text { handling with assistive devices }\end{array}$ & 15.4 & 6.6 & 9.4 & 0.4 & $0.2-0.7$ & 0.002 \\
\hline $\begin{array}{l}\text { Height adjustable beds in } \\
\text { nursing care provision }\end{array}$ & 28.5 & 21.8 & 2.4 & 0.7 & $0.5-1.1$ & 0.124 \\
\hline $\begin{array}{l}\text { Treatment of patients in the } \\
\text { highest patient classification } \\
\text { system category }\end{array}$ & 4.1 & 11.8 & 5.8 & 3.2 & $1.2-8.1$ & 0.016 \\
\hline $\begin{array}{l}\text { Work with the computer } \geq 2 \mathrm{~h} \\
\text { per day }\end{array}$ & 40.7 & 24.7 & 12.0 & 0.5 & $0.3-0.7$ & 0.001 \\
\hline $\begin{array}{l}\text { Regular exercises to prevent } \\
\text { LBP }\end{array}$ & 27.6 & 52.0 & 21.9 & 2.8 & $1.8-4.4$ & $<0.001$ \\
\hline Recreation and sports in youth & 60.2 & 44.3 & 9.6 & 0.5 & $0.4-0.8$ & 0.002 \\
\hline $\begin{array}{l}\text { Recreation and sports at } \\
\text { present }\end{array}$ & 37.4 & 20.3 & 15.1 & 0.4 & $0.3-0.7$ & $<0.001$ \\
\hline Watching $T V \geq 2 h$ per day & 52.8 & 51.7 & $<0.1$ & 1.0 & $0.6-1.4$ & 0.829 \\
\hline$B M I \geq 25$ & 25.2 & 39.3 & 8.2 & 1.9 & $1.2-3.0$ & 0.004 \\
\hline
\end{tabular}

Table 1. Univariate analysis of risk factors for development of LBP

The results of univariate statistics show that three risk factors were not significantly connected to development of LBP. These were manual patient transfer and material 
handling, height adjustable beds in nursing care provision and watching TV $\geq 2 \mathrm{~h}$ per day. LBP incidents were marked as rare if respondents reported none, one or two incidents while employed as nursing personnel ( $\mathrm{n}=123$ or $21.2 \%$ ).

Results of the follow-up multivariate analysis are presented in Table 2. Three risk factors were calculated as independent predictors for development of LBP. Other significant risk factors on the univariate level failed to achieve statistical significance. The prediction quality of the calculated regression model also resulted in statistical significance $\left(X^{2}=99.577, \mathrm{df}=15\right.$, $\mathrm{p}<0.001)$. The regression model explained $24.5 \%$ of the original variance.

\begin{tabular}{|c|c|c|c|c|c|c|}
\hline \multirow[t]{2}{*}{ Risk factor } & \multicolumn{2}{|c|}{ LBP (in \%) } & \multirow[t]{2}{*}{$\chi^{2}$} & \multirow[t]{2}{*}{ OR } & \multirow[t]{2}{*}{$95 \% \mathrm{CI}$} & \multirow[t]{2}{*}{ P-value } \\
\hline & $\begin{array}{c}\text { rare } \\
(\mathrm{n}=123)\end{array}$ & $\begin{array}{c}\text { frequent } \\
(\mathrm{n}=458)\end{array}$ & & & & \\
\hline Age $\geq 40 \mathrm{y}$ & 26.0 & 53.9 & 2.0 & 2.3 & $0.7-7.2$ & 0.152 \\
\hline Female gender & 75.6 & 86.5 & 3.0 & 1.7 & $0.9-3.0$ & 0.084 \\
\hline Duration of employment $\geq 20 y$ & 26.8 & 54.6 & 0.0 & 1.1 & $0.4-3.6$ & 0.847 \\
\hline $\begin{array}{l}\text { Duration of employment in } \\
\text { current position } \geq 15 y\end{array}$ & 32.5 & 51.7 & 0.6 & 0.8 & $0.4-1.4$ & 0.453 \\
\hline Frequent manual lifting $>10 \mathrm{~kg}$ & 43.1 & 63.5 & 14.4 & 2.4 & $1.5-3.9$ & $<0.001$ \\
\hline $\begin{array}{l}\text { Manual patient transfer and } \\
\text { material handling }\end{array}$ & 10.6 & 16.2 & 1.9 & 1.6 & $0.8-3.3$ & 0.166 \\
\hline $\begin{array}{l}\text { Patient transfer and material } \\
\text { handling with assistive devices }\end{array}$ & 15.4 & 6.6 & 1.5 & 0.6 & $0.3-1.3$ & 0.219 \\
\hline $\begin{array}{l}\text { Height adjustable beds in } \\
\text { nursing care provision }\end{array}$ & 28.5 & 21.8 & 0.2 & 0.9 & $0.5-1.5$ & 0.638 \\
\hline $\begin{array}{l}\text { Treatment of patients in the } \\
\text { highest patient classification } \\
\text { system category }\end{array}$ & 4.1 & 11.8 & 1.9 & 2.0 & $0.8-5.5$ & 0.164 \\
\hline $\begin{array}{l}\text { Work with the computer } \geq 2 \mathrm{~h} \\
\text { per day }\end{array}$ & 40.7 & 24.7 & 3.3 & 0.6 & $0.4-1.0$ & 0.071 \\
\hline $\begin{array}{l}\text { Regular exercises to prevent } \\
\text { LBP }\end{array}$ & 27.6 & 52.0 & 16.8 & 2.8 & $1.7-4.6$ & $<0.001$ \\
\hline Recreation and sports in youth & 60.2 & 44.3 & 0.4 & 0.9 & $0.5-1.4$ & 0.539 \\
\hline $\begin{array}{l}\text { Recreation and sports at } \\
\text { present }\end{array}$ & 37.4 & 20.3 & 7.1 & 0.5 & $0.3-0.8$ & 0.008 \\
\hline Watching $\mathrm{TV} \geq 2 \mathrm{~h}$ per day & 52.8 & 51.7 & 0.6 & 0.8 & $0.5-1.3$ & 0.447 \\
\hline$B M I \geq 25$ & 25.2 & 39.3 & 2.9 & 1.6 & $0.9-2.6$ & 0.091 \\
\hline
\end{tabular}

Nagelkerke $\mathrm{R}^{2}=0.245$

Table 2. Multivariate analysis of risk factors for development of LBP (model $\chi^{2}=99.577$, $\mathrm{df}=15, \mathrm{p}<0.001)$

According to $\chi^{2}$ values in Table 2, regular exercises to prevent LBP represented the highest risk for development of LBP (OR 2.8, 95\%CI 1.7-4.6). This result shows that nursing personnel started with preventive exercises when it was too late and LBP was already developed. In case of rare LBP problems, $72.4 \%$ of nursing personnel without frequent LBP 
problems were not performing any preventive exercises. The second ranked risk factor was frequent manual lifting $>10 \mathrm{~kg}$ (OR 2.4, 95\% CI 1.5-3.9). Of the nursing personnel who developed LBP on a frequent basis, $63.5 \%$ reported that their care activities are connected to frequent manual lifting of considerable weight. The third ranked risk factor was conducted in better physical condition by regular recreation and sports, which reduced the risk for frequent development of LBP (OR 0.5, 95\% CI 0.3-0.8). Only $20.3 \%$ of the nursing personnel who reported frequent LBP were regularly engaged in recreation and sports; this percentage was considerably lower compared to nursing personnel without recreational and sporting interests.

\section{Discussion}

Frequent LBP was reported in $78.8 \%$ of cases, which was similar to results in previous studies (Karahan \& Bayraktar, 2004). The strongest risk factor for development of LBP was found in the absence of preventive exercises to strengthen back muscles. Nursing personnel may not be aware of LBP risks and start with preventive exercises when it is already too late and LBP episodes become frequent. Exercises to prevent LBP are considered useful although there is little scholarly agreement on the kind of preventive exercising that should be undertaken or which intensity leads to best possible results (Burton et al., 2005; Byrne et al., 2006). In addition, our results indicate that recreation and sports may reduce risk of developing LBP, although the odds ratio was not as evident. Similar results were obtained by Linton and van Tulder (2001) and Burton et al. (2005).

Manual lifting is the best known risk for development of LBP, especially if the weight is considerable, of frequent nature, or both (Marras et al., 1999; Retsas \& Pinikahaba, 2000; Bongers et al., 2002). For many years now, the international literature called to implement working rules for reduction of physical stressors on the human body. The best solution to the problem may be the 'zero lift policy' by using assistive devices when providing nursing care (Collins et al., 2004; Nelson et al., 2006). When considering that the manual lifting hazard grows with advancing age and that the retirement age is increasing, reaching retirement without developing LBP may become a challenge for nursing personnel (Engkvist, 2008). Surprisingly, our results did not significantly confirm this, although odds ratio of 2.3 for higher age $(\geq 40)$ pointed in the same direction. The financial costs of LBP treatment should not be considered only during employment, because in retirement problems usually increase and become chronic (Turk, 2005). In such cases the financial costs for health insurance may turn out to be considerable for the rest of the person's life due to the need for analgesic drugs and physiotherapy.

Improved physical conditions for nursing personnel is not something that the public directly connects with the purpose of nursing care, which is primarily to offer physical and psychosocial help and care to sick and frail people. Society connects nursing care primarily with virtues like solace, attentiveness, empathy etc., and less with physical strength. It is therefore odd to expect from nursing personnel to expose their low backs far beyond recommended thresholds when manually transferring patients. In that manner, the proposal to reduce workload by grouping nursing personnel or employing specialists as lift teams would considerably reduce exposure to low back problems (Charney, 1997), but due to lack of staff or additional staff costs it is difficult to consider either organisation or employment of such teams. Yet, Charney (1997) argued that if sick leave, subsequent insurance and 
medical costs, staff turnover and other possible negative side effects of LBP development are taken into account, then this equation should turn out positive in the long run.

Regular prevention exercises to strengthen back and abdominal muscles lead to improved physical strength and relief to the musculoskeletal when lifting manually or needing to use force (Linton \& van Tulder, 2001; Burton et al., 2005). Some other studies, however, only partially confirmed that such an approach prevents developing LBP (Lahad et al., 1994; Maher, 2000; Rainville et al., 2004). Nevertheless, improved physical condition is popular and represents a modern life style to reduce the daily stress. LBP prevention should be incorporated in the regular daily working schedule of nursing personnel in particular. There are several possible ways to realise this, but the most important is to gain the support of legislation and employers. In our opinion it would be best if employees could decide on their own which prevention strategy is most suitable for them, considering their abilities and expectations, and in this way employers, for example, would show their contribution with time subsidies (approximately 15-30 minutes daily). It is also very important to consider that prevention activities and especially sports activities can also lead to health contraindications (Burton et al., 2005).

Members of the nursing personnel who are not interested in recreation and sports should not be forced to improve their physical condition in such a way. Nevertheless, only a small effort is needed for significant improvement (Feng et al., 2007). It is our belief that exercises to prevent LBP should be clearly promoted. Employees in Slovenia must participate in various trainings to keep their working licence, but there is no obligation to train how to maintain vitality. The orientation should be on education about physical stressors and routines how to strengthen the musculoskeletal system to at least try to keep the lifelong resistance. Mitchell et al. (2009) suggested that lifestyle and psychological factors associated with LBP should begin to be addressed during undergraduate study.

\subsection{Suggestions for future research}

The results conducted in this research are much as expected, yet in some cases also surprising, especially that the frequent manual lifting $>10 \mathrm{~kg}$ was the only significant occupational risk factors for development of LBP. Our expectations were oriented towards duration of employment and age as two typical risk factors for any kind of health risk. We also expected that patient transfer and material handling with assistive devices would reduce the risk for developing LBP. At the University Clinical Center Maribor, for example, surgical departments have better technical equipment then internal medical departments. Surgical departments are housed in new buildings with wide corridors and also in patients' rooms there is more space between beds, although conditions differ according to circumstances; usually in winter time there are more injuries. The typical problem in nearly all hospital departments is lack of space around toilet bowls and bath tubs, doors are not wide enough for easy access with wheelchairs or stretchers. These architectural barriers make solutions for a 'zero lift policy' for nursing personnel a far dream. Engkvist et al. (1995) exposed some of these problems scientifically.

Further research is needed, including the risk factors involved in this research and more precise details about specific manual patient transfer or manual material handling (patient transfer to wheelchair, stretcher or bath tub, repositioning in bed, washing, toileting etc.). 
We also propose that future research should include specific types of recreation and sports activities (running, cycling, fitness, hiking etc.) and types of regular exercises to prevent LBP (yoga, Pilates, aerobics, abdominal training, traditional morning exercises etc.). Noninclusion of this data represents some justified self-criticism of our research design and criticism of other similar studies. Results about risk factors are primarily too general and seldom offer precise information which manual lifting activities should be avoided and which recreational, sporting and preventive activities should be fostered.

\subsection{Study limitations}

The sample in our research was gathered from a single hospital. However, our literature review showed that several international hospitals face similar problems to those in Slovenia, primarily because of inadequate staffing levels and occupational stress (time distress, physical and psychological fatigue), that consequently cause pain and injuries to nursing personnel (Hollingdale \& Warin, 1997; Vasiliadou et al., 1997; Aiken et al., 2001; Smedley et al., 2003; Videman et al., 2005). We believe that the University Clinical Center Maribor represents typical European and international hospitals supplying comprehensive health care services and disease treatments. Therefore, our research sample included nursing personnel from all areas or departments that are determined by international medicine.

A concern represents a possible non-response. From 900 distributed questionnaires, 237 or $26 \%$, remained unevaluated. There is a possibility of impact on the results because we could not included variance of nursing personnel who did not respond to the research. Nevertheless, the response rate of $74 \%$ was, according to international literature, very good (Trinkoff et al., 2003).

Given the cross-sectional study design and the collection of data by self-report, these findings must, however, be interpreted with caution, because self-report may reflect denial, deception, or difficulty in recall (Trinkoff et al., 2003).

\section{Conclusion}

Because of various health problems in relation to LBP, which may result in absence from work and consequently increased pressure from employers, it seems reasonable that nursing personnel pay more attention how to maintain a healthy spine. Awkward body postures and manual lifting may be difficult to avoid due to the nature of nursing. Little interest from employers to purchase assistive devices and improve working conditions means that it is important for nursing personnel to find their own suitable LBP prevention strategy. For example, preventive exercises can be more physically oriented, such as abdominal training, or be more vigorous like aerobics, yoga or Pilates. Each prevention strategy may lead to some improvement and if there is dissatisfaction it is easy to stop and to try something else.

The international literature is alarmed about the occupational tasks of nursing personnel that involve a heavy physical burden connected to manual patient and material handling. Nursing personnel are pushed into these risky tasks without much consideration about their health risks. Manual patient transfer and lifting of heavy burden is not defined as an occupational duty or task of nursing personnel. The current shortage of nursing personnel who avoid this ever more physically and psychological stressful occupation, and the 
increasing need for nursing care of a frail older population must lead to legislation, and to employers to search for solutions to improve working environment.

The LBP problem is very complex one. The battle against spine diseases should include several professions and multidirectional approaches. We see two crucial points where the most important work against LBP in nursing personnel must be executed. First the nursing schools should include the knowledge about spine problems, risk factors and prevention strategies in their educational programme. Second the employers should be aware of costbenefit of LBP prevention and take care of optimal work organisation and ergonomics with proper technical equipment for diminution of heavy physical work of nursing personnel.

\section{References}

Aiken, L.H.; Clarke, S.P.; Sloane, D.M.; Sochalski, J.A.; Busse, R.; Clarke, H.; Giovannetti, P.; Hunt, J.; Rafferty, A.M. \& Shamian, J. (2001). Nurses' reports on hospital care in five countries. Health affairs, Vol.20, No.3, (May 2001), pp. 43-53, ISSN 0278-2715

Andersson, G.B. (1999). Epidemiological features of chronic low-back pain. Lancet, Vol.354, No.9178, (August 1999), pp. 581-585, ISSN 1470-2045

Ando, S.; Ono, Y.; Shimaoka, M.; Hiruta, S.; Hattori, Y.; Hori, F. \& Takeuchi, Y. (2000). Associations of self estimated workloads with musculoskeletal symptoms among hospital nurses. Occupational and Environmental Medicine, Vol.57, No.3, (March 2000), pp. 211-216, ISSN 1351-0711

Balantič, Z. \& Zupan, A. (2003). Measurements of respiratory capacity in patients with neuromuscular diseases. Experimental Lung Research, Vol.29, No.8, (December 2003), pp. 537-548, ISSN 0190-2148

Bigos, S.; Spengler, D.; Martin, N.; Zeh, J.; Fisher, L.; Nachemson, A. \& Wang, M.H. (1986). Back injuries in industry: A retrospective study. II, Injury factors. Spine, Vol.11, No.3, (April 1986). pp. 246-241, ISSN 0362-2436

Bongers, P.M.; Kremer, A.M. \& ter Laak, J. (2002). Are psychosocial factors, risk factors for symptoms and signs of the shoulder, elbow, or hand/wrist?: A review of the epidemiological literature. American Journal of Industrial Medicine, Vol.41, No.5, (May 2002), pp. 315-342, ISSN 0271-3586

Bot, S.D.M.; Terwee, C.B.; van der Windt, D.A.W.M.; Feleus, A.; Bierma-Zeinstra, S.M.; Knol, D.L.; Bouter, L.M. \& Dekker, J. (2004). Internal consistency and validity of a new physical workload questionnaire. Occupational and Environmental Medicine, Vol.61, No.12, (December 2004), pp. 980-986, ISSN 1351-0711

Burton, A.K.; Balagué, F.; Cardon, G.; Eriksen, H.R.; Henrotin, Y.; Lahad, A.; Leclerc, A.; Müller, G.; van der Beek, A.J. \& COST B13 Working Group on European Guidelines for Prevention in Low Back Pain, (2005). How to prevent low back pain. Best Practice \& Research Clinical Rheumatology, Vol.19, No.4, (August 2005), pp. 541-555, ISSN 1521-6942

Byrne, K.; Doody, C. \& Hurley D.A. (2006). Exercise therapy for low back pain: A small-scale exploratory survey of current physiotherapy practice in the Republic of Ireland acute hospital setting. Manual Therapy, Vol.11, No.4, (November 2006), pp. 272-278, ISSN 1356-689X

Charney, W. (1997). The lift team method for reducing back injuries: a 10-hospital study, AAOHN Journal, Vol.45, No.6, (June 1997), pp.300-304, ISSN 0891-0162 
Collins J.W.; Wolf, L.; Bell, J. \& Evanoff, B. (2004). An evaluation of a "best practices" musculoskeletal injury prevention program in nursing homes. Injury Prevention, Vol.10, No.4, (August 2004), pp. 206-211, ISSN 1353-8047

Council Directive 89/391/EEC. (1989). The introduction of measures to encourage improvements in the safety and health of workers at work, Brussels, 5.9.2011, Available from

http:/ / eur-lex.europa.eu/LexUriServ/LexUriServ.do?uri=CELEX:31989L0391: en:HTML

Council Directive 90/269/EEC. (1990). the minimum health and safety requirements for the manual handling of loads where there is a risk particularly of back injury to workers, Brussels, 15.9.2011, Available from

http:/ / eur-lex.europa.eu/LexUriServ/LexUriServ.do?uri=CELEX:31990L0269: en:HTML

Croft, P.R.; Papageorgiou, A.C.; Thomas, E.; Macfarlane, G.J. \& Silman, A.J. (1999). Shortterm physical risk factors for new episodes of low back pain. Prospective evidence from the South Manchester back pain study. Spine, Vol.24, No.15, (August 1999), pp. 1556-1561, ISSN 0362-2436

Cromie, J.E.; Robertson, V.J. \& Best, M.O. (2000). Work-related musculoskeletal disorders in physical therapists: prevalence, severity, risks, and responses. Physical Therapy, Vol.80, No.4, pp. 336-351, ISSN 0031-9023

Daltroy, L. (1997). A controlled trial of an educational program to prevent low back injuries. The New England Journal of Medicine, Vol.337, No.5, (July 1997), pp. 322-328, ISSN 0028-4793

Davidson, M. \& Keating, J.L. (2002). A comparison of five low back disability questionnaires: reliability and responsiveness. Physical Therapy, Vol.82, No.1, (January 2002), pp. 8-24, ISSN 0031-9023

Daynard, D.; Yassi, A.; Cooper, J.E.; Tate, R.; Norman, R. \& Wells, R. (2001). Biomechanical analysis of peak and cumulative spinal loads during simulated patient-handling activities: a substudy of a randomized controlled trial to prevent lift and transfer injury of health care workers. Applied Ergonomics, Vol.32, No.3, (June 2001), pp. 199214, ISSN 0003-6870

DiMattio, M.J.K.; Roe-Prior, P. \& Carpenter, D.R. (2010). Intent to Stay: A Pilot Study of Baccalaureate Nurses and Hospital Nursing. Journal of Professional Nursing, Vol.26, No.5, (September-October 2010), pp. 278-286, ISSN 8755-7223

Elford, W.; Straker, L. \& Strauss, G. (2000). Patient handling with and without slings: an analysis of the risk of injury to the lumbar spine. Applied Ergonomics, Vol.31, No.2, (April 2000), pp. 185-200, ISSN 0003-6870

Engkvist, I.-L.; Hagberg, M.; Wigaeus-Hjelm, E.; Menckel, E.; Ekenvall, L. \& PROSA Study Froup. (1995). Interview protocols and ergonomics checklist for analysing overexertion back accidents among nursing personnel. Applied Ergonomics, Vol.26, No.3, (June 1995), pp. 213-220 ISSN 0003-6870

Engkvist, I.-L.; Hagberg, M.; Hjelm, E.W.; Menckel, E.; Ekenvall, L. \& PROSA study group. (1998). The accident process preceding overexertion back injuries in nursing personnel. Scandinavian Journal of Work, Environment and Health, Vol.24, No.5, (October 1998), pp. 367-375, ISSN 0355-3140 
Engkvist, I.-L. (2008). Back injuries among nurses - A comparison of the accident processes after a 10-year follow-up. Safety Science, Vol.46, No.2, (February 2008), pp. 291-301, ISSN 0925-7535

European Agency for Safety and Health at Work. (2008). European legal requirements relating to work-related musculoskeletal disorders, Brussels, 05.09.2011, Available from

http://osha.europa.eu/en/topics/msds/legislation_html

Fairbank, J.C.T. \& Pynsent, P.B. (2000). The Oswestry Disability Index. Spine, Vol.25, No.22, (November 2000), pp. 2940-2953, ISSN 0362-2436

Feng, C.-K.; Chen, M.-L. \& Mao, I.-F. (2007). Prevalence of and risk factors for different measures of low back pain among female nursing aides in Taiwanese nursing homes. In: BMC Musculoskeletal Disorders, 8:52, (June 2007), Available from http:/ / www.biomedcentral.com/1471-2474/8/52.

Ferguson, S. \& Marras, W. (1997). A literature review of low back disorder surveillance measures and risk factors. Clinical Biomechanics, Vol.12, No.4, (June 1997), pp. 211226, ISSN 0268-0033

Frymoyer, J.W.; Pope, M.H.; Costanza, M.C.; Rosen, J.C.; Goggin, J.E. \& Wilder, D.G. (1980). Epidemiologic studies of low-back pain. Spine, Vol.5, No.5, (September-October 1980), pp. 419-423, ISSN 0362-2436

Goldman, R.H.; Jarrard, M.R.; Kim, R.; Loomis, S. \& Atkins, E.H. (2000). Prioritizing back injury risk in hospital employees: application and comparison of different injury rates. Journal of Occupational and Environmental Medicine, Vol.42, No.6, (June 2000), pp. 645-652, ISSN 1351-0711

Hansson, E.K. \& Hansson, T.H. (2005). The costs for persons sick-listed more than one month because of low back or neck problems. A two-year prospective study of Swedish patients. European Spine Journal, Vol. 14, No.4, (May 2005), pp. 337-345, ISSN 0940-6719

Heliovaara, M.; Knekt, P. \& Aromaa, A. (1987). Incidence and risk factors of herniated lumbar intervertebral disc or sciatica leading to hospitalization. Journal of Chronic Diseases, Vol.40, No.3, (March 1987), pp. 251-258, ISSN 0021-9681

Hollingdale, R. \& Warin, J. (1997). Back pain in nursing and associated factors: a study. Nursing Standard, Vol.11, No.39, (June 1997), pp. 35-38, ISSN 0029-6570

Hoogendoorn, W.E.; van Poppel, M.N.; Bongers, P.M.; Koes, B.W. \& Bouter, L.M. (1999). Physical load during work and leisure time as risk factors for back pain. Scandinavian Journal of Work, Environment and Health, Vol.25, No.5, (October 1999), pp. 387-403, ISSN 0355-3140

Hui, L.; Ng, G.Y.; Yeung, S.S. \& Hui-Chan, C.W. (2001). Evaluation of physiological work demands and low back neuromuscular fatigue on nurses working in geriatric wards. Applied Ergonomics, Vol.32, No.5, (October 2001), pp. 479-483, ISSN 00036870

Hye-Knudsen, C.T.; Schibye, B.; Hjortskov, N. \& Fallentin, N. (2004). Trunk motion characteristics during different patient handling tasks. International Journal of Industrial Ergonomics, Vol.33, No.4, (April 2004), pp. 327-337, ISSN 0169-8141

Karahan, A. \& Bayraktar, N. (2004). Determination of the usage of body mechanics in clinical settings and the occurrence of low back pain in nurses. International Journal of Nursing Studies, Vol.41, No.1, (January 2004), pp. 67-75, ISSN 0020-7489 
Kelsey, J.L.; Githens, P.B.; White, A.A. 3rd; Holford, T.R.; Walter, S.D.; O'Connor, T.; Ostfeld, A.M.; Weil, U.; Southwick, W.O. \& Calogero, J.A. (1984). An epidemiological study of lifting and twisting on the job and the risk for acute prolapsed lumbar intervertebral disk. Journal of Orthopedic Research, Vol.2, No.1, (January 1984), pp. 61-66, ISSN

Kerr, M.S.; Frank, J.W.; Shannon, H.S.; Norman, R.W.K.; Wells, R.P.; Neumann, W. P.; Bombardier, C. \& Ontario Universities Back Pain Study Group (2001). Biomechanical and psychosocial risk factors for low back pain at work. American Journal of Public Health, Vol.91, No.7, (July 2001), pp. 1069-1075, ISSN 1741-3842

Lagerstrom, M.; Wenemark, M.; Hagberg, M. \& Hjelm, E.W. (1995). Occupational and individual factors related to musculoskeletal symptoms in five body regions among Swedish nursing personnel. International Archives of Occupational and Environmental Health, Vol.68, No.1, (January 1995), pp. 27-35, ISSN 0340-0131

Lagerstrom, M. \& Hagberg, M. (1997). Evaluation of a 3 year education and training program for nursing personnel at a Swedish hospital. AAOHN Journal, Vol.45, No.2, (February 1997), pp. 83-92, ISSN 0891-0162

Lahad, A.; Malter, A.D.; Berg, A.O. \& Deyo, R.A. (1994). The effectiveness of four interventions for the prevention of low back pain. Journal of American Medical Association, Vol.272, No.16, (October 1994), pp. 1286-1291, ISSN 0098-7484

Larese, F. \& Fiorito, A. (1994). Musculoskeletal disorders in hospital nurses: a comparison between two hospitals, Ergonomics, Vol.37, No.7, (July 1994), 1205-1211, ISSN 00140139

Linton, S.J. \& van Tulder, M.W. (2001). Preventive interventions for back and neck pain problems: What is the evidence? Spine, Vol.26, No.7, (April 2001), pp. 778-787, ISSN 0362-2436

Maher, C.; Latimer, J. \& Refshauge, K. (1999). Prescription of activity for low back pain: What works? The Australian Journal of Physiotherapy, Vol.45, No.2, (June 1999), pp. 121-132, ISSN 0004-9514

Maher, C.G. (2000). A systematic review of workplace interventions to prevent low back pain. The Australian Journal of Physiotherapy, Vol.46, No.4, (December 2000), pp. 259269, ISSN 0004-9514

Marras, W.S.; Davis, K.G.; Kirking, B.C. \& Bertsche, P.K. (1999). A comprehensive analysis of low-back disorder risk and spinal loading during the transferring and repositioning of patients using different techniques. Ergonomics, Vol.42, No.7, (July 1999), pp. 904-926, ISSN 0014-0139

Massey, L.; Esain, A. \& Wallis, M. (2009). Managing the complexity of nurse shortages: A case study of bank and agency staffing in an acute care Trust in Wales, UK. International Journal of Nursing Studies, Vol.46, No.7, (July 2009), pp. 912-919, ISSN 0020-7489

Menzel, N.N.; Brooks, S.M.; Bernard, T.E. \& Nelson, A. (2004). The physical workload of nursing personnel: association with musculoskeletal discomfort. International Journal of Nursing Studies, Vol.41, No.8, (November 2004), pp. 859-867, ISSN 00207489

Mitchell, T.; O'Sullivan, P.B.; Smith, A.; Burnett, A.F.; Straker, L.; Thornton, J. \& Rudd, C.J. (2009). Biopsychosocial factors are associated with low back pain in female nursing 
students: A cross-sectional study. International Journal of Nursing Studies, Vol.46, No.5, (May 2009), pp. 678-688, ISSN 0020-7489

Nelson, A.; Lloyd, J.; Menzel, N. \& Gross, C. (2003a). Preventing nursing back injuries: redesigning patient handling tasks. AAOHN Journal, Vol.51, No.3, (March 2003), pp. 126-134, ISSN 0891-0162

Nelson, A.; Fragala, G. \& Menzel, N. (2003b). Myths and facts about back injuries in nursing. American Journal of Nursing, Vol.103, No.2, (February, 2003), pp. 32-40, ISSN 0002936X

Nelson, A.; Matz, M.; Chen, F.; Siddharthan, K.; Lloyd, J. \& Fragala, G. (2006). Development and evaluation of a multifaceted ergonomics program to prevent injuries associated with patient handling tasks. International Journal of Nursing Studies, Vol.43, no.6, (August, 2006), pp. 717-733, ISSN 0020-7489

NIOSH - National Institute for Occupational Safety and Health. (1981). Work Practices Guide for Manual Lifting, NIOSH DHHS Publication No. 81-122, Cincinnati, USA

NIOSH - National Institute for Occupational Safety and Health. (1994). Applications Manual for the Revised NIOSH Lifting Equation, NIOSH DHHS Publication No. 94-110, Cincinnati, USA

Owen, B.D. \& Garg, A. (1989). Patient handling tasks perceived to be most stressful by nursing assistants, In: Advances in Industrial Ergonomics and Safety, A. Mital, (Ed.), 775-781, I. Taylor and Francis, ISBN 978-0850664935, London, United Kingdom

Owen BD. (2000). Preventing injuries using an ergonomic approach. AORN Journal, Vol.72, No.6, (December 2000), pp. 1031-1036, ISSN 0001-2092

Owen, B.D.; Keene, K. \& Olson, S. (2002). An ergonomic approach to reducing back/shoulder stress in hospital nursing personnel: a five year follow up. International Journal of Nursing Studies, Vol.39, No.3, (March 2002), pp. 295-392, ISSN 0020-7489

Polit, D.F. (January 1996). Data Analysis and Statistics for Nursing Research, Prentice-Hall, ISBN 978-0838563298, Upper Saddle River, NJ, USA

Puotiniemi, T.A. \& Kyngäs, H. (2004). The coping of an adolescent who has been in psychiatric inpatient care and her mother in every day life. Journal of Psychiatry and Mental Health Nursing, Vol.11, No.6, (December 2004), pp. 675-682, ISSN 1351-0126

Rainville, J.; Hartigan, C.; Martinez, E.; Limke, J.; Jouve, C. \& Finno, M. (2004). Exercise as a treatment for chronic low back pain. The Spine Journal, Vol.4, No.1, (JanuaryFebruary, 2004), pp. 106-115, ISSN 1529-9430

Retsas, A. \& Pinikahaba, J. (2000). Manual handling activities and injuries among nurses: an Australian hospital study. Journal of Advanced Nursing, Vol.31, No.4, (April 2000), pp. 874-883, ISSN 0309-2402

Rubin, D.I. (2007). Epidemiology and risk factors for spine pain. Neurologic Clinics, Vol.25, No.2, (May 2007), pp. 353-371 ISSN 0733-8619

Santaguida, P.L.; Pierrynowski, M.; Goldsmith, C. \& Fernie, G. (2005). Comparison of cumulative low back loads of caregivers when transferring patients using overhead and floor mechanical lifting devices. Clinical Biomechanics, Vol. 20, No.9, (November 2005), pp. 906-916, ISSN 0268-0033

Shehab, D. \& Al-Jarallah, K. (2005). Nonspecific low-back pain in Kuwaiti children and adolescents: Associated factors. Journal of Adolescent Health, Vol.36, No.1, (January 2005), pp. 32-35, ISSN 1054-139X 
Smedley, J.; Egger, P.; Cooper, C. \& Coggon, D. (1995). Manual handling activities and risk of low back pain in nurses. Occupational and Environmental Medicine, Vol.52, No.3, (March 1995), pp. 160-163, ISSN 1351-0711

Smedley, J.; Inskip, H.; Trevelyan, F.; Buckle P.; Cooper C. \& Coggon D. (2003). Risk factors for incident neck and shoulder pain in hospital nurses. Occupational and Environmental Medicine, Vol.60, No.11, (November 2003), pp. 864-869, ISSN 13510711

Trinkoff, A.M.; Lipscomb, J.A.; Geiger-Brown, J.; Storr, C.L. \& Brady, B.A. (2003). Perceived Physical Demands and Reported Musculoskeletal Problems in Registered Nurses. American Journal of Preventive Medicine, Vol.24, No.3, (April 2003), pp. 270-275, ISSN 0749-3797

Turk, Z. (2005). Socialnomedicinski vidiki bolečine v križu. Rehabilitacija, Vol.4, No.3-4, (December 2005), pp. 9-12, ISSN 1580-9315

van Tulder, M.W.; Koes, B.W. \& Bouter, L.M. (1995). A cost-of-illness study of back pain in The Netherlands. Pain, Vol.62, No.2, (August 1995), pp. 233-240, ISSN 0304-3959

Vasiliadou, A.; Karvountzis, G.; Roumeliotis, D.; Soumilas, A.; Plati, C. \& Nomikos, I. (1997). Factors associated with back pain in nursing staff: a survey in Athens, Greece, International Journal of Nursing Practice, Vol.3, No.1, (March 1997), pp. 15-20, ISSN $1322-7114$

Videman, T.; Ojajärvi, A.; Riihimäki, H. \& Troup, J.D. (2005). Low back pain among nurses: a follow-up beginning at entry to the nursing school. Spine, Vol.30, No.20, (October 2005), pp. 2334-2341, ISSN 0362-2436

Zhuang, Z.; Stobbe, T.J.; Hsiao, H.; Collins, J.W. \& Hobbs, G.R. (1999). Biomechanical evaluation of assistive devices for transferring residents. Applied Ergonomics, Vol.30, No.4, (August 1999), pp. 285-294, ISSN 0003-6870

Zhuang, Z.; Stobbe T.J.; Collins J.W.; Hsiao, H. \& Hobbs, G.R. (2000). Psychophysical assessment of assistive devices for transferring patients/residents. Applied Ergonomics, Vol.31, No.1, (February 2000), pp. 35-44, ISSN 0003-6870

Wenig, C.M.; Schmidt, C.O.; Kohlmann, T. \& Schweikert, B. (2009). Costs of back pain in Germany, European Journal of Pain, Vol.13, No.3, (March 2009), pp. 280-286, ISSN 1090-3801

Whiting, W.C.; Ronald, F. \& Zernicke, R.F. (2008). Biomechanics of Musculoskeletal Injury (2nd ed), Human Kinetics, ISBN 978-0736054423, Champaign, IL, USA

WHO. (2006). BMI Classification. World Health Organization, Geneva, 17.08.2011, Available from http:/ /apps.who.int/bmi/index.jsp?introPage=intro_3.html

Winkelmolen, G.H.; Landeweerd, J.A. \& Drost, M.R. (1994). An evaluation of patient lifting techniques. Ergonomics, Vol. 37, No.5, (May 1994), pp. 921-932, ISSN 0014-0139 


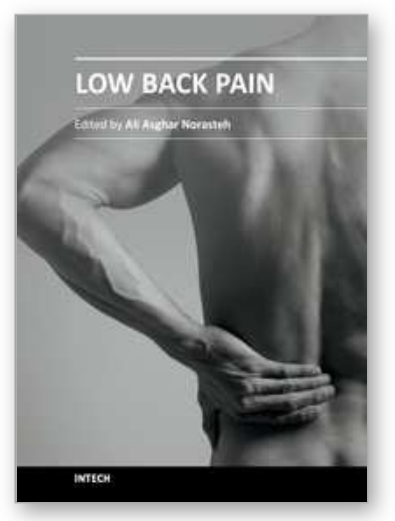

\section{Low Back Pain}

Edited by Dr. Ali Asghar Norasteh

ISBN 978-953-51-0599-2

Hard cover, 352 pages

Publisher InTech

Published online 09, May, 2012

Published in print edition May, 2012

This book includes two sections. Section one is about basic science, epidemiology, risk factors and evaluation, section two is about clinical science especially different approach in exercise therapy. I envisage that this book will provide helpful information and guidance for all those practitioners involved with managing people with back pain-physiotherapists, osteopaths, chiropractors and doctors of orthopedics, rheumatology, rehabilitation and manual medicine. Likewise for students of movement and those who are involved in re-educating movement-exercise physiologists, Pilates and yoga teachers etc.

\section{How to reference}

In order to correctly reference this scholarly work, feel free to copy and paste the following:

Jadranka Stričević, Zvone Balantič, Zmago Turk, Dušan Čelan and Majda Pajnkihar (2012). Occupational and Environmental Risk Factors for Development of Low Back Pain in Hospital Nursing Personnel, Low Back Pain, Dr. Ali Asghar Norasteh (Ed.), ISBN: 978-953-51-0599-2, InTech, Available from:

http://www.intechopen.com/books/low-back-pain/occupational-and-environmental-risk-factors-fordevelopment-of-low-back-pain-in-hospital-nursing-per

\section{INTECH}

open science | open minds

\section{InTech Europe}

University Campus STeP Ri

Slavka Krautzeka 83/A

51000 Rijeka, Croatia

Phone: +385 (51) 770447

Fax: +385 (51) 686166

www.intechopen.com

\section{InTech China}

Unit 405, Office Block, Hotel Equatorial Shanghai

No.65, Yan An Road (West), Shanghai, 200040, China

中国上海市延安西路65号上海国际贵都大饭店办公楼405单元

Phone: +86-21-62489820

Fax: $+86-21-62489821$ 
(C) 2012 The Author(s). Licensee IntechOpen. This is an open access article distributed under the terms of the Creative Commons Attribution 3.0 License, which permits unrestricted use, distribution, and reproduction in any medium, provided the original work is properly cited. 